\title{
The Attitudes and Perceptions Towards Animal Welfare of Staff Employed in the Care and Handling of Animals During Animal Transport in Muş Province
}

\author{
Betül ÇELİK ${ }^{*}$, Zehra BOZKURT ${ }^{2}$ \\ ${ }^{1}$ Republic of Turkey Ministry of Food Agriculture and Livestock, Department of Training Extention and Publications, Ankara/TÜRKIYE \\ ${ }^{2}$ Afyon Kocatepe University, Faculty of Veterinary Medicine, Department of Animal Husbandry, Afyonkarahisar/TÜRKIYYE
}

Corresponding author e-mail: zhra.bozkurt@gmail.com

* This paper is summarized from the PhD thesis entitled "Effect of transport period and loading density of sheep to welfare and animal welfare perception and attitude of personnel assigned in animal transport" (Thesis number: 2013-007)

\# This study received the support of Afyon Kocatepe University Scientific Research Projects Coordination Unit with Project number 12.SAĞ.BIL.03, Turkey.

\begin{abstract}
The study was carried out with the participation of 80 people consisting of transporters, drivers and animal care personnel who deal with animal handling processes and live in the centre of Muss province and its districts where most of animal transporters settle. The questionnaire consists of three parts; the socio-demographic characteristics of participants are examined in part one. Part two analyses the attitude scale based on cognitive, emotional and behavioural aspects of animal welfare during transport; and, the third part evaluates the perception scale such as shelter, feeding, staff, health and other factors which determine the perception of staff towards the factors affecting animal welfare. The results obtained from the research showed that perception and attitude of the personnel assigned for animal transportation might affect the welfare of animals during transportation. Staff employed in animal handling and transportation in Mus Province is insufficient with respect to animal welfare knowledge and experience, and their attitude is shaped mostly by cognitive and emotional aspects. This study has come to the conclusion that in order to improve human-animal relations and its quality and ultimately animal welfare, the staff employed in the whole process must be evaluated thoroughly, and the fact that most transportations out of Mus consist of at least 8 or more hours of traveling should be taken into consideration in order to benefit from staff training and cognitive behavioural intervention techniques.
\end{abstract}

Key Words: Animal Transport, Animal Welfare, Attitude, Perception, Staff

\section{Muş İlinde Canlı Hayvan Nakilleri Sırasında Hayvan Bakım ve İdaresini Yapan Personelin Hayvan Refahına İlişkin Algı ve Tutumları}

ÖZ

$\mathrm{Bu}$ araştırma Muş il merkezi ve bazı ilçelerinde yaşayan 80 hayvan nakliyecisi, araç sürücüsü ve hayvan bakıcısının katılımıyla yapılmıştır. Anket üç bölümden oluşmaktadır; birinci bölümde katılımcıların sosyo-demografik özellikleri incelenmiştir. İkinci bölüm bilişsel, duygusal ve davranışsal boyutlara dayanan hayvan refahı tutum ölçeği ve üçüncü bölüm nakil personelinin hayvan refahını etkileyen barındırma, besleme, personel, sağlık ve diğer faktörlere ilişkin alg1 ölçeğinden oluşmaktadır. Araştırmada elde edilen sonuçlar, hayvan nakillerinde görevli personelin hayvan refahı algı ve tutumunun idare ettikleri hayvan nakillerinde hayvanların refahını etkileyebileceğini göstermiştir. Muş ilinde gerçekleşen hayvan nakillerinde görevli personelin hayvan refahı konusunda bilgi ve becerisinin yetersiz olduğu ve hayvan refahına ilişkin personel tutumunda bilişsel ve duygusal boyutların ağırlık taşıdığ1 anlaşılmıştır. Sonuç olarak çoğunluğu sekiz saati aşan uzun yol nakiller olan Muş ilinde gerçekleşen nakillerde insan-hayvan etkileşimlerinin düzeyini ve kalitesini arttırmak için nakilde görevli personelin alg1 ve tutumunun geliştirilmesi için personel eğitimi ve bilişsel davranışçı müdahale tekniklerinden yararlanılabileceği düşünülmektedir.

Anahtar Kelimeler: Hayvan Nakli, Hayvan Refahı, Tutum, Alg1, Personel

To cite this article: Çelik B, Bozkurt Z. The Attitudes and Perceptions Towards Animal Welfare of Staff Employed in the Care and Handling of Animals During Animal Transport in Muş Province. Kocatepe Vet J. 2016; 9(4):294-303. 


\section{INTRODUCTION}

There is increasing evidence that intensive methods of animal production, transportation and slaughter cause a dramatic decrease in animal welfare (Napolitano et al 2013). The most common reasons for this decrease are high-housing density, poor domestic shelter conditions (Baxter et al 1983), the use of concentrated feed (Kan et al 1998), genetic modifications, improvement attempts aimed at efficiency only (Ormandy et al 2011), growth and efficiency enhancing additives (Kan et al 1998), transport and slaughter conditions (Pascual-Alonso et al 2016, Grandin 2005), as well as human-animal interactions (Waiblinger et al 2002). Whether these conditions can be improved or continue to pose a threat to the welfare of the animals depends particularly on the staff in charge of animal care, feeding and handling.

Perceptions, attitudes and behavioural effects of farmers and farm workers on animal welfare have been examined comprehensively (Herzog et al., 1991, Köhler, 2001, Paul and Serpell 1993, Furnham and Heyes 1993; Hills 1995). The staff's attitude towards animal welfare can change depending on demographics, professional experience, social and market demands while their interest in the animals' welfare can be affected by bureaucracy, additional costs, loss of competitiveness, high welfare standards and education (Van Poucke et al 2006, Dockes and Kling-Eveillard 2006, Kauppinen et al 2012). K1lıç and Bozkurt (2013) have determined that sheep breeders' perception of animal welfare is closely associated with the welfare standard of the animals in their farm. After the animals are picked from the production unit for transportation, the factors such as standards of loading and unloading, road and weather conditions, means of transport conditions, attitudes of the animal keepers and the drivers create some effect on animal welfare (Broom 2008, Trunkfield and Broom 1990). Although it is known that the transportation process is mainly responsible for the formation of negative human-animal relations, occurrence of stress, fear and sorrow due to the animals coming across with new and unfamiliar people, and different environments including new objects and events, there is limited amount of research on the relationship between transporters' and keepers' attitudes and perception towards animal welfare (Gonyou et al 1986, Boivin et al 1992).

Recent years have seen an increase in public concern for animal welfare during transport in Turkey as well as in the EU. Turkey's national legislation on farm animal welfare during transportation is compatible with Council Regulation (EC) No 1/2005 on the protection of animals during transport. Amendments on long-distance transports will enter into force after 31 December 2016, based on the amendment published on the Official Gazette No. 29577 of 29 December 2015. Live animal transport is performed intensely from northeast to the west of Turkey especially in a few months, and most of slaughter houses are mostly centred in Aegean, Marmara and Central Anatolia regions. Based on the geographical structure of Turkey, a limited number of main routes are used for long transports constituting about 2000 $\mathrm{km}$. Therefore, in every year, many dairy cows, beef cattle, sheep and goats are generally transported from the eastern provinces of Turkey to the western regions. The perceptions and attitudes of the animal transport staff are crucial for the impacts of transportation on the welfare of animal exposed mostly to long-distance transports in Turkey.

With the participation of staff making contact with livestock during transport in Mus province, which is located in the starting point of a long-distance transport route, this study was conducted (1) to describe the perceptions regarding factors which affect animal welfare, to confirm the attitudes towards animal welfare during animal transport, and (2) to determine whether socio-demographic factors affect perceptions and attitudes in relation to animal welfare.

\section{MATERIALS AND METHODS}

\section{Data Collection}

The research has taken into focus the animal transporters, drivers and animal care personnel who work with live animals during transport in Mus Province. Muş was chosen due to its geographical location. The city is located on one of the busiest routes used for short and long animal transportation in Turkey. This route goes through Central Anatolia, Aegean and Marmara regions.

The research was carried out with the participation of 80 people consisting of transporters, drivers and animal care personnel who are employed in animal handling processes and live in the centre or some districts of Muş province where most of animal transporters settle (Korkut, Hasköy and Varto). The stratified sampling method which is one type of probability sampling methods (taking into account the different tasks in the animal transport process) was used to select the participants. Eighty face to face interviews were performed; 68 of them were taken into consideration following the elimination of incomplete or invalid questionnaires.

The scales developed by Kilıç and Bozkurt (2014) were used in the study for describing the perceptions regarding the factors which affect animal welfare and 
determining the attitudes towards animal welfare during animal transport. The questionnaire consists of three parts; the socio-demographic characteristics of the participants are examined in part one. Beside the scale used, some variables such as gender, age, educational background, experience in animal transport, job and salary satisfaction, social security benefits, childhood in the rural or urban areas, current settlement status (city or village), interest in animal welfare and beliefs with regard to the most effective factors on animal welfare were included to determine the personal characteristics of animal transport staff in the questionnaire. Part two evaluates the attitude scale based on cognitive, emotional and behavioural aspects of animal welfare during transport (including 20, 10 and 12 items belonging to 3 dimensions respectively). Lastly, the third part analyses the perception scale such as shelter, feeding, staff, health (veterinary inspection and animal emotion) and other factors (including 6 , $10,6,15$ and 10 items belonging to 5 dimensions respectively) that determine the perception of the staff towards the factors affecting animal welfare.

\section{Statistical Analysis}

The attitudes and perceptions of the animal transport staff were evaluated using the Likert (1967) type scale. The levels of agreement for the attitude scale and the levels of affect for the perception scale were scored in 5 scores (None $=1$, Low $=2$, Moderate $=3, \mathrm{High}=4$ and Completely=5). In our research, perceptions on factors affecting animal welfare and attitudes regarding animal welfare during transport of animal transport staff were described by calculating means and standard deviations for each dimension. SPSS 14.01 for Windows was used to determine the statistical results.

\section{RESULTS}

\section{Demographic features and individual opinions}

In terms of group structure, the whole staff working for animal transport, who was interviewed in this study, consisted of males. $42.6 \%$ of the participants were older than 41 years and rate of personnel who graduated from primary school was $42.6 \%$ while only $13.2 \%$ of the participants had a university degree. The monthly salary of $76 \%$ of the participants was under 1750 TL while $44 \%$ of participant stated that they did not have social security. $58.8 \%$ of the participants grew up in urban areas while $51.5 \%$ of them live in rural areas. $25 \%$ of participants lived their childhood in urban area.

According to participants' responses, $44.1 \%$ of the participants had an experience in animal transportation for less than 11 years while $14.7 \%$ of them had more than 24 years. A majority $(85.3 \%)$ of those involved in the transport of livestock have stated to enjoy their job. On the other hand $45.6 \%$ of the participants stated that they had no interest in animal welfare while $66.2 \%$ of them considered this matter as unimportant. $60.3 \%$ of the personnel dealing with animals during transport stated that natural conditions affect animal welfare the most. $66.2 \%$ and $72.1 \%$ of the participants believed the transportation process greatly affects animal health and welfare in a negative manner respectively. But those who believed the process would create stress in the animals were lower $(54.5 \%)$. The fact that giving breaks (resting) during the transportation would not relieve the stress of animals was not agreed much (10.3\%). $66.2 \%$ of the participants believed that pushing involuntary animals from the back or hitting them during loading and unloading is an effective method.

\section{Perceptions towards animal welfare}

The means and standard deviations of dimensions related to animal welfare perception scale applied in the research are given in Table 1 (feeding, shelter and staff status) and Table 2 (health and other status). The arithmetic means of participants' responses on the subject of "feeding status" showed that the most important factors affecting animal welfare were believed to be "properties of feed given to animals" ( $\overline{\mathrm{X}}=4,85)$ and "vegetation properties in pasture" $(\overline{\mathrm{X}}$ $=4,69)$ while "weaning at an early age" $(\bar{X}=4,25)$ and "feeding equipment and other physical conditions" $(\bar{X}=4,50)$ were believed to be the least important factors. When we examined the mean calculated for "shelter status" in the scale, we saw that the participants held the perception that issues related with "ventilation status or system of shelters" were the most effective $(\overline{\mathrm{X}}=4,69)$ whereas "sound and noise inside shelter" $(\overline{\mathrm{X}}=4,13)$ and "gas composition inside shelter" ( $\bar{X}=4,29)$ were believed to be least likely effective factors on animal welfare.

Regarding "staff status", the participants believed that "staff behavior to animals" $(\overline{\mathrm{X}}=4,69)$ and "pleasure of staff on their job" $(\bar{X}=4,69)$ were more effective than "staff motivation (working conditions, salary, so on)" $(\overline{\mathrm{X}}=4,16)$ and "staff education level" $(\overline{\mathrm{X}}=4,44)$ in terms of animal welfare (Table 1). The most positive approach of animal transport staff in terms of animal welfare was regarding "staff behavior to animals" $(\overline{\mathrm{X}}=4,69)$ and "pleasure of staff on their job" $(\bar{X}=4,69)$ whereas the most negative comments were regarding "staff motivation (working conditions, salary, so on)" ( $\overline{\mathrm{X}}$ $=4,16)$ and "staff education level" $(\overline{\mathrm{X}}=4,44)$ (Table 1).

As regard to the results given in Table 2, while questioning the health status affecting animal welfare, "health of the animals checked regularly by a veterinarian" $(\bar{X}=4,81)$ and "method of health treatment" $(\bar{X}=4,76)$ were considered to be the most important while "neutering (bulls, dogs, horses etc.)" $(\overline{\mathrm{X}}=3,88)$ and "cutting tails, paws, clipping 
nails, beak, wings, fingers etc." $(\overline{\mathrm{X}}=3,99)$ were considered to be the least important ones. Evaluation of other status affecting animal welfare showed that "animals' feeling of safety" $(\bar{X}=4,56)$ and "transportation conditions" $(\bar{X}=4,50)$ were the most important factors while "sacrificing animals" ( $\bar{X}=3,81)$ and "naming of farm animals" $(\bar{X}=4,12)$ are the least important ones.

\section{Attitudes towards animal welfare}

When evaluating cognitive aspects of attitudes affecting animal welfare during transport, it has been showed that, "conditions of shelter in which animals live affect animal welfare" $(\bar{X}=4,85)$, "nutritional requirements of animals affect animal welfare" ( $\overline{\mathrm{X}}$ $=4,84$ ) and "animal health conditions affect animal welfare" ( $\bar{X}=4,81)$ were believed to be the most important factors but on the other hand "sacrificing animals affects animal welfare" ( $\bar{X}$ $=3,38$ ), "purchase of food products produced in animal friendly production system (milk, egg, meat etc.) affects animal welfare" $(\bar{X}=3,63)$ and "legal legislation regarding animals has an impact on animal welfare" ( $\overline{\mathrm{X}}=3,66)$ were considered to be the least effective factors (Table 3). Evaluation of emotional aspects of attitudes affecting animal welfare during transport showed that "violence against animals is ferocity" ( $\bar{X}=4,78)$ and "I believe happy animals will give better quality products (meat, milk, eggs, etc.)" ( $\bar{X}=4,75)$ were the most important while the factors "I recognise that animals are individuals" $(\bar{X}=3,87)$ and "I believe that there is a relation between domestic violence and intentional harm against animals" $(\bar{X}=3,94)$ are considered to be the least effective ones (Table 4).

Behavioural aspects of attitudes affecting animal welfare during transport in the questionnaire revealed that "I encourage people to treat animals well" $(\bar{X}=4,60)$ and "I approach with compassion to street animals" ( $\overline{\mathrm{X}}=4,57)$ were the most agreed points while "I can easily identify the label on the product whether it has been produced in animal friendly production system" $(\bar{X}=3,47)$ and "I'm interested in animal welfare" $(\overline{\mathrm{X}}=3,91)$ were the least agreed ones (Table 5).

\section{DISCUSSION}

This study carried out in the city of Muş and its districts only involved men. This is thought to be the result of mainly male-dominated labour force of Turkey along with animal transportation sector bias of animal keeping requiring high physical labour force and the region's socio-cultural background and structure restricting women from joining work force while encouraging men to do the hard work (Anonim 2013, Karpat Çatalbaş 2015, Kellert and
Berry 1987). Herzog et al (1991) reported that correlations between the masculine and feminine dimensions of sex role orientation were in opposite directions on all animal attitude measures.

The participants of the study received mainly low levels of education (only $20 \%$ were middle or high school graduated) and most of them were at middle age or older. This is thought to negatively affect the animal welfare perception and attitude of transporters and animal keepers according to the correlation between educational level and positive attitudes towards animals (Kellert 1988; Pifer et 1994, Hemsworth and Coleman 1998, Kılıç et al 2013) and increased concern for animal welfare in the middle aged or younger (Maria 2006). On the other hand, the majority of the participants stated that they had been dealing with animal transportation for more than 12 years $(55 \%)$. A majority $(75 \%)$ of those involved in the transport of animals have stated that they had been raised in urban areas, and it is expected that traditional animal husbandry experience affects animal welfare during transportation under their responsibility in a positive manner. This shows that the participants are people who do this work in the long part of their life almost, thus exhibiting a higher rate of experience through working in animal trade, animal handling and care during loading or unloading processes, and mostly they are vehicle owners or drivers. The emotional aspect of the staff caring animals would greatly affect the welfare of the animals during transport because Kıliç and Bozkurt (2013) have reported that perception of farmers, who do their job happily, towards animal welfare is affected in a positive manner. The fact that wages are below the minimum wage is believed to create a discontent among the staff, causing less work satisfaction and motivation. Less motivation would greatly affect the morale of the staff causing a decrease in animal welfare quality (Hemsworth and Coleman, 1998, Coleman 2004, Hemsworth and Coleman 2010). It can be argued that $75 \%$ of participants lived their childhood in the village and it would be a positive impact on animal welfare as reported by Napolitano et al (2013).

The staff's perception that feeding and health factors are the main determinants of animal welfare is a positive finding. On the other hand, the participants have perceived that some animal husbandry practices such as forced molting, contesting or holding fights, slaughtering conditions, culling and even animal violence, which result in higher stress, pain, agony and suffering on animals, do not greatly affect animal welfare. Most of them even believe that sterilization and cutting of tails, claws, nails, beaks and wings are the least affecting factors on animal welfare. It was thought that there were differences in perception of animal transport 
staff with respect to the effects of conventional practices of animal breeding on animal health and animal welfare. These findings indicate that the transport personnel in Mus need more training about animal welfare to manage the transport successfully and to modify their attitudes and behaviour as well. Insufficient knowledge and training of animal keepers especially on the subject of animal health, animal welfare and pain management, leads to poorly practiced techniques, causing a worsening in animal welfare. It is also seen that these people, who transport animals to a completely new environment, evaluate animal welfare as the physical well-being of animals, and they also consider that animals which are fed better to grow faster are healthier. Considering animal welfare just from the point of the health status of animal is an attempt to rid of the guilt factor, and justify their contradictory perceptions. As a matter of fact, the participants believed that protecting the animals from natural conditions such as hunger and cold is an effective method for better animal welfare. This thus creates a resistance when trying to change their perspective and attitude towards animal welfare (Furnham and Heyes 1993).

The results of research showed that the perception of the animal transport staff towards animal welfare is in line with the cognitive part of animal welfare attitudes of them. Although the participants believed that human-animal relations, the transport process, and fear and insecurity affect animal welfare, they also believed that the physical farm conditions are greater determinants when compared to the transportation conditions. It is also seen that these people believe that considering animals as individuals or even naming them, slaughtering or sacrificing animals, the activities of animal protection activists and purchasing higher priced animal friendly food products do not have any effect on animal welfare. As reviewed and reported by some reserachers the cognitive agents such as the low education level and the poor skills and knowledge based solely on traditional practices of animal husbandry, incomplete knowledge on modern and large institutions, animal health and animal welfare are thought to create a negative effect on the animal welfare considering that these people have close contact with animals and their transportation (İnceoğlu 2010, Kellert 1988, Pifer et al 1994, Hemsworth and Coleman 1998, Kielland et al 2010, English et al 1992, Bozkurt et al 2013).

Although the staff employed in animal transportation believes that animals can feel pain and have emotions and deserve to be in good condition, they also agree that animals are created for the sake of mankind. It is understood that the emotional perspectives of these people towards animal welfare are closely related to the values system in which they were brought up. On the other hand staff employed in animal transportation believes in that their behaviour towards animals effects the others' perception towards them (İnceoğlu 2010). Considering the low education level of the participants and their close relations with sensitive subjects such as race, religion and ethnic origin, their perspectives towards animal welfare is inevitably and mostly based on emotional aspects (İnceoğlu 2010, Tozkoparan 2013, Kutanis 2013). Hills (1995) stated that a positive relationship was hypothesized between empathy for animals and "belief in animal mind".

Staff responsible for animal care during transportation stated that attitude towards animal welfare is closely related with the factors such as approaching animals with affection, following legal guidelines that protect animal welfare, supporting animal protection activists and buying expensive products that have passed animal welfare guidelines. However, they have also stated that they did not have a tendency to inform others about the needs of animals and how to improve their welfare. It is thought that these contradictions arise from the battle between what is expected from them as a society and their own perspectives towards the matter. This is due to the individual effort to adapt to the group which they believe they belong to and abiding by the group's perspectives towards the matter even if it contradicts what they believe in or what they were raised to believe in (İnceoğlu 2010).

This research showed that there was a contradiction between their attitudes towards animal welfare and their perceptions during the process of transportation. One of the most prominent contradictions is in the state of treating animals like individuals. Although participants believed that animals should be treated as individuals on a cognitive scale, when evaluated through emotional perspective, they mostly agreed that they "would not treat animals as individuals." In a similar fashion, staff who stated that they would buy animal friendly products even though they were more expensive ( $70 \%$ of participants) and they believe transportation affects animal health and causes stress, they partly contradicted themselves in stating that transportation conditions do not affect animal welfare and animals that are unwilling to be loaded and unloaded are made to do so by using force. Some researchers reported similar findings (Hemsworth and Coleman 1998, Kellert 1988).

This study ultimately showed that the staff employed for handling animals approach the issue of animal welfare in a three-dimensional field comprised of cognitive, behavioural and emotional. Any change in one of these three aspects would cause a chain reaction to change the others in order to achieve a 
balance and unity in the process. As Kutanis (2013) stated, an individual who changes an approach towards a subject in a positive or a negative manner rearranges their psychological and behavioural approach as well. It is thought that the independent variables of the person (genetic factors, physical conditions, direct experience in handling process, demographic characteristics and personality) alongside with their social status (socialization, adapting to social norms, member of a group and social status) affect each individual's approach

towards animal welfare when dealing with animal transportation (English et al 1992, Coleman et al 1998, Hemsworth et al 2000, Kielland et al 2010).

Table 1. Descriptive statistics regarding the feeding, shelter and staff status factors affecting animal welfare perception scale of animal handling staff during transport

\begin{tabular}{|c|c|c|c|c|c|c|c|}
\hline \multirow{2}{*}{ Factors/ Articles } & \multicolumn{5}{|c|}{ Effect Level (\%) } & \multirow[b]{2}{*}{$\bar{X}$} & \multirow[b]{2}{*}{ SD } \\
\hline & 1 & 2 & 3 & 4 & 5 & & \\
\hline \multicolumn{8}{|l|}{ Feeding status } \\
\hline Properties of feed given to animals & 0,0 & 0,0 & 1,5 & 11,8 & 86,8 & 4,85 & 0,40 \\
\hline Properties of the water given to animals & 0,0 & 1,5 & 5,9 & 19,1 & 73,5 & 4,65 & 0,66 \\
\hline Feeding equipment and other physical conditions & 1,5 & 1,5 & 5,9 & 27,9 & 63,2 & 4,50 & 0,80 \\
\hline Size of the outdoor grazing area (pasture) & 1,5 & 0,0 & 5,9 & 16,2 & 76,5 & 4,66 & 0,73 \\
\hline Vegetation properties in pasture & 0,0 & 1,5 & 5,9 & 14,7 & 77,9 & 4,69 & 0,65 \\
\hline Weaning at an early age & 5,9 & 1,5 & 16,2 & 14,7 & 61,8 & 4,25 & 1,15 \\
\hline \multicolumn{8}{|l|}{ Shelter status } \\
\hline Sanitary conditions of shelters & 2,9 & 2,9 & 4,4 & 5,9 & 83,8 & 4,65 & 0,93 \\
\hline Ventilation status or system of shelters & 1,5 & 1,5 & 5,9 & 8,8 & 82,4 & 4,69 & 0,78 \\
\hline Air temperature inside shelter & 1,5 & 2,9 & 7,4 & 13,2 & 75,0 & 4,57 & 0,87 \\
\hline Air humidity inside shelter & 1,5 & 2,9 & 7,4 & 19,1 & 69,1 & 4,51 & 0,87 \\
\hline Gas composition inside shelter & 5,9 & 4,4 & 10,3 & 13,2 & 66,2 & 4,29 & 1,19 \\
\hline Lighting condition of shelters & 5,9 & 1,5 & 10,3 & 14,7 & 67,6 & 4,37 & 1,12 \\
\hline Isolation condition of shelters & 2,9 & 1,5 & 13,2 & 11,8 & 70,6 & 4,46 & 0,98 \\
\hline Sound and noise inside shelter & 10,3 & 4,4 & 11,8 & 8,8 & 64,7 & 4,13 & 1,37 \\
\hline Floor condition of shelter & 5,9 & 4,4 & 4,4 & 11,8 & 73,5 & 4,43 & 1,15 \\
\hline Higher stocking density & 5,9 & 0,0 & 4,4 & 8,8 & 80,9 & 4,59 & 1,03 \\
\hline \multicolumn{8}{|l|}{ Staff status } \\
\hline Staff behavior to animals & 1,5 & 1,5 & 4,4 & 11,8 & 80,9 & 4,69 & 0,76 \\
\hline Staff education level & 1,5 & 2,9 & 11,8 & 17,6 & 66,2 & 4,44 & 0,92 \\
\hline Staff training on animal welfare & 1,5 & 2,9 & 5,9 & 22,1 & 67,6 & 4,51 & 0,86 \\
\hline Staff experience & 4,4 & 2,9 & 2,9 & 14,7 & 75,0 & 4,53 & 1,01 \\
\hline Staff motivation (working conditions, salary,so on) & 13,2 & 2,9 & 4,4 & 13,2 & 66,2 & 4,16 & 1,42 \\
\hline Pleasure of staff on their job & 1,5 & 0,0 & 5,9 & 13,2 & 79,4 & 4,69 & 0,72 \\
\hline
\end{tabular}


Table 2. Descriptive statistics regarding the health and other status factors affecting animal welfare perception scale of animal handling staff during transport

\begin{tabular}{|c|c|c|c|c|c|c|c|}
\hline \multirow{2}{*}{ Factors / Articles } & & \multicolumn{5}{|c|}{ Effect Level (\%) } & \multirow[b]{2}{*}{ SD } \\
\hline & & 1 & 2 & 3 & 4 & 5 & \\
\hline \multicolumn{8}{|l|}{ Health status } \\
\hline Method of health treatment & 1,5 & 0,0 & 1,5 & 14,7 & 82,4 & 4,76 & 0,63 \\
\hline $\begin{array}{l}\text { Minerals and vitamins given to animals under veterinary } \\
\text { control }\end{array}$ & 2,9 & 0,0 & 2,9 & 17,6 & 76,5 & 4,65 & 0,81 \\
\hline Pain or suffering & 4,4 & 1,5 & 5,9 & 14,7 & 73,5 & 4,51 & 1,00 \\
\hline Happiness of animals & 1,5 & 1,5 & 5,9 & 13,2 & 77,9 & 4,65 & 0,79 \\
\hline Stress and fatigue of animals & 4,4 & 1,5 & 5,9 & 14,7 & 73,5 & 4,51 & 1,00 \\
\hline Culling of animals due to disease (killing) & 10,3 & 7,4 & 8,8 & 17,6 & 55,9 & 4,01 & 1,38 \\
\hline Neutering (bulls, dogs, horses, etc.) & 14,7 & 8,8 & 5,9 & 14,7 & 55,9 & 3,88 & 1,52 \\
\hline $\begin{array}{l}\text { Cutting tails, paws, clipping nails, beak, wings, fingers, } \\
\text { etc. }\end{array}$ & 11,8 & 2,9 & 14,7 & 16,2 & 54,4 & 3,99 & 1,38 \\
\hline $\begin{array}{l}\text { Applications such as forcible shedding of feathers and } \\
\text { horn blunting }\end{array}$ & 10,3 & 2,9 & 10,3 & 29,4 & 47,1 & 4,00 & 1,28 \\
\hline Animal fighting (dog, cocks, bulls) & 10,3 & 4,4 & 5,9 & 16,2 & 63,2 & 4,18 & 1,34 \\
\hline Violence against animals & 8,8 & 1,5 & 8,8 & 16,2 & 64,7 & 4,26 & 1,24 \\
\hline Slaughterhouse conditions & 11,8 & 0,0 & 10,3 & 17,6 & 60,3 & 4,15 & 1,33 \\
\hline Usage of electric prods or other devices & 11,8 & 1,5 & 4,4 & 14,7 & 67,6 & 4,25 & 1,34 \\
\hline Animal racing (like dog racing) & 10,3 & 8,8 & 5,9 & 10,3 & 64,7 & 4,10 & 1,42 \\
\hline $\begin{array}{l}\text { Health of the animals checked regularly by a } \\
\text { veterinarian }\end{array}$ & 1,5 & 0,0 & 1,5 & 10,3 & 86,8 & 4,81 & 0,60 \\
\hline \multicolumn{8}{|l|}{ Other status } \\
\hline Scaring and frightening conditions for animals & 5,9 & 2,9 & 8,8 & 14,7 & 67,6 & 4,35 & 1,14 \\
\hline Conditions related to breeding & 2,9 & 2,9 & 5,9 & 25,0 & 63,2 & 4,43 & 0,95 \\
\hline Relations between animals and their babies & 2,9 & 2,9 & 2,9 & 25,0 & 66,2 & 4,49 & 0,92 \\
\hline Technical devices in production cycle & 4,4 & 0,0 & 11,8 & 14,7 & 69,1 & 4,44 & 1,01 \\
\hline Animals' feeling of safety & 1,5 & 5,9 & 4,4 & 11,8 & 76,5 & 4,56 & 0,94 \\
\hline Recognition of animals as individuals & 2,9 & 4,4 & 7,4 & 17,6 & 67,6 & 4,43 & 1,01 \\
\hline Naming of farm animals & 10,3 & 2,9 & 13,2 & 11,8 & 61,8 & 4,12 & 1,34 \\
\hline Transportation conditions & 1,5 & 4,4 & 8,8 & 13,2 & 72,1 & 4,50 & 0,94 \\
\hline Sacrificing animals & 22,1 & 0,0 & 8,8 & 13,2 & 55,9 & 3,81 & 1,62 \\
\hline Leaving animals in streets (like cats, dogs ) & 8,8 & 1,5 & 10,3 & 5,9 & 73,5 & 4,34 & 1,27 \\
\hline
\end{tabular}

Table 3. Descriptive statistics of cognitive aspects of the attitude scale

\begin{tabular}{|c|c|c|c|c|c|c|c|}
\hline \multirow[t]{2}{*}{ Factors / Articles } & \multicolumn{5}{|c|}{ Agreement level (\%) } & \multirow{2}{*}{$\bar{X}$} & \multirow[b]{2}{*}{ SD } \\
\hline & 1 & 2 & 3 & 4 & 5 & & \\
\hline Conditions of shelter in which animals live affect animal welfare & 1,5 & 0,0 & 1,5 & 5,9 & 91,2 & 4,85 & 0,58 \\
\hline Nutritional requirements of animals affect animal welfare & 1,5 & 0,0 & 0,0 & 10,3 & 88,2 & 4,84 & 0,56 \\
\hline Animal health conditions affect animal welfare & 1,5 & 0,0 & 1,5 & 10,3 & 86,8 & 4,81 & 0,60 \\
\hline Staff responsible for the care of animals has an impact on animal welfare & 2,9 & 1,5 & 5,9 & 19,1 & 70,6 & 4,53 & 0,91 \\
\hline $\begin{array}{l}\text { Conditions of transporting animals from one place to another have an } \\
\text { impact on animal welfare }\end{array}$ & 2,9 & 0,0 & 7,4 & 22,1 & 67,6 & 4,51 & 0,87 \\
\hline Conditions that may lead to nervosity affect animal welfare & 1,5 & 2,9 & 8,8 & 22,1 & 64,7 & 4,46 & 0,89 \\
\hline $\begin{array}{l}\text { Technical equipment used during the product acquirement process have } \\
\text { an impact on animal welfare }\end{array}$ & 1,5 & 2,9 & 4,4 & 23,5 & 67,6 & 4,53 & 0,84 \\
\hline Relationship with the offspring of animals affects animal welfare & 1,5 & 4,4 & 7,4 & 19,1 & 67,6 & 4,47 & 0,92 \\
\hline $\begin{array}{l}\text { Equipment and technology used in animal production affect animal } \\
\text { welfare }\end{array}$ & 7,4 & 4,4 & 8,8 & 17,6 & 61,8 & 4,22 & 1,23 \\
\hline Feeling of safety affects welfare of the animals & 8,8 & 2,9 & 19,1 & 16,2 & 52,9 & 4,01 & 1,29 \\
\hline Recognition of animals as individuals affects animal welfare & 11,8 & 7,4 & 8,8 & 13,2 & 58,8 & 4,00 & 1,44 \\
\hline Slaughtering of livestock affects animal welfare & 14,7 & 4,4 & 16,2 & 11,8 & 52,9 & 3,84 & 1,48 \\
\hline Naming animals affects animal welfare & 16,2 & 5,9 & 7,4 & 16,2 & 54,4 & 3,87 & 1,52 \\
\hline Conditions during transport affect animal welfare & 7,4 & 1,5 & 11,8 & 20,6 & 58,8 & 4,22 & 1,18 \\
\hline Sacrificing animals affects animal welfare & 26,5 & 8,8 & 8,8 & 11,8 & 44,1 & 3,38 & 1,71 \\
\hline Leaving animals in streets (like cats, dogs) affects animal welfare & 16,2 & 7,4 & 8,8 & 14,7 & 52,9 & 3,81 & 1,54 \\
\hline $\begin{array}{l}\text { Activities of non-governmental organizations supporting animal } \\
\text { protection affect animal welfare }\end{array}$ & 14,7 & 7,4 & 11,8 & 19,1 & 47,1 & 3,76 & 1,48 \\
\hline Legal legislation regarding animals has an impact on animal welfare & 17,6 & 10,3 & 7,4 & 17,6 & 47,1 & 3,66 & 1,57 \\
\hline Interaction between animals and human has an impact on animal welfare & 10,3 & 5,9 & 2,9 & 30,9 & 50,0 & 4,04 & 1,31 \\
\hline $\begin{array}{l}\text { Purchase of food products produced in animal friendly production } \\
\text { system (milk, egg, meat etc.) affects animal welfare }\end{array}$ & 14,7 & 11,8 & 11,8 & 19,1 & 42,6 & 3,63 & 1,50 \\
\hline
\end{tabular}


Table 4. Descriptive statistics of emotional aspects of the attitude scale

\begin{tabular}{|c|c|c|c|c|c|c|c|c|}
\hline \multirow[b]{2}{*}{ Factors / Articles } & & \multicolumn{5}{|c|}{ Agreement level (\%) } & \multirow[b]{2}{*}{$\bar{X}$} & \multirow[b]{2}{*}{ SD } \\
\hline & & 1 & 2 & 3 & 4 & 5 & & \\
\hline I recognise that animals are individuals & 11,8 & 5,9 & 16,2 & 16,2 & 50,0 & 3,87 & & 1,40 \\
\hline Animals have been created for human use & 4,4 & 2,9 & 7,4 & 13,2 & 72,1 & 4,46 & & 1,06 \\
\hline I believe that animals have rights just like people & 0,0 & 2,9 & 8,8 & 13,2 & 75,0 & 4,60 & & 0,78 \\
\hline I believe animals are "sentient being" & 0,0 & 1,5 & 5,9 & 11,8 & 80,9 & 4,72 & & 0,64 \\
\hline I can understand if an animal is in pain or suffering & 1,5 & 2,9 & 7,4 & 5,9 & 82,4 & 4,65 & & 0,86 \\
\hline Violence against animals is ferocity & 1,5 & 0,0 & 2,9 & 10,3 & 85,3 & 4,78 & & 0,64 \\
\hline $\begin{array}{l}\text { I believe that there is a relation between domestic } \\
\text { violence and intentional harm against animals }\end{array}$ & 13,2 & 2,9 & 13,2 & 17,6 & 52,9 & 3,94 & & 1,41 \\
\hline I believe that animals have rights like people & 2,9 & 1,5 & 8,8 & 17,6 & 69,1 & 4,49 & & 0,94 \\
\hline $\begin{array}{l}\text { I believe that attitudes of people towards animals affect } \\
\text { others' perception towards them }\end{array}$ & 2,9 & 2,9 & 14,7 & 20,6 & 58,8 & 4,29 & & 1,02 \\
\hline $\begin{array}{l}\text { I believe happy animals will give better quality products } \\
\text { (meat, milk, eggs, etc.) }\end{array}$ & 1,5 & 0,0 & 4,4 & 10,3 & 83,8 & 4,75 & & 0,68 \\
\hline
\end{tabular}

Table 5. Descriptive statistics of behavioural aspects of the attitude scale

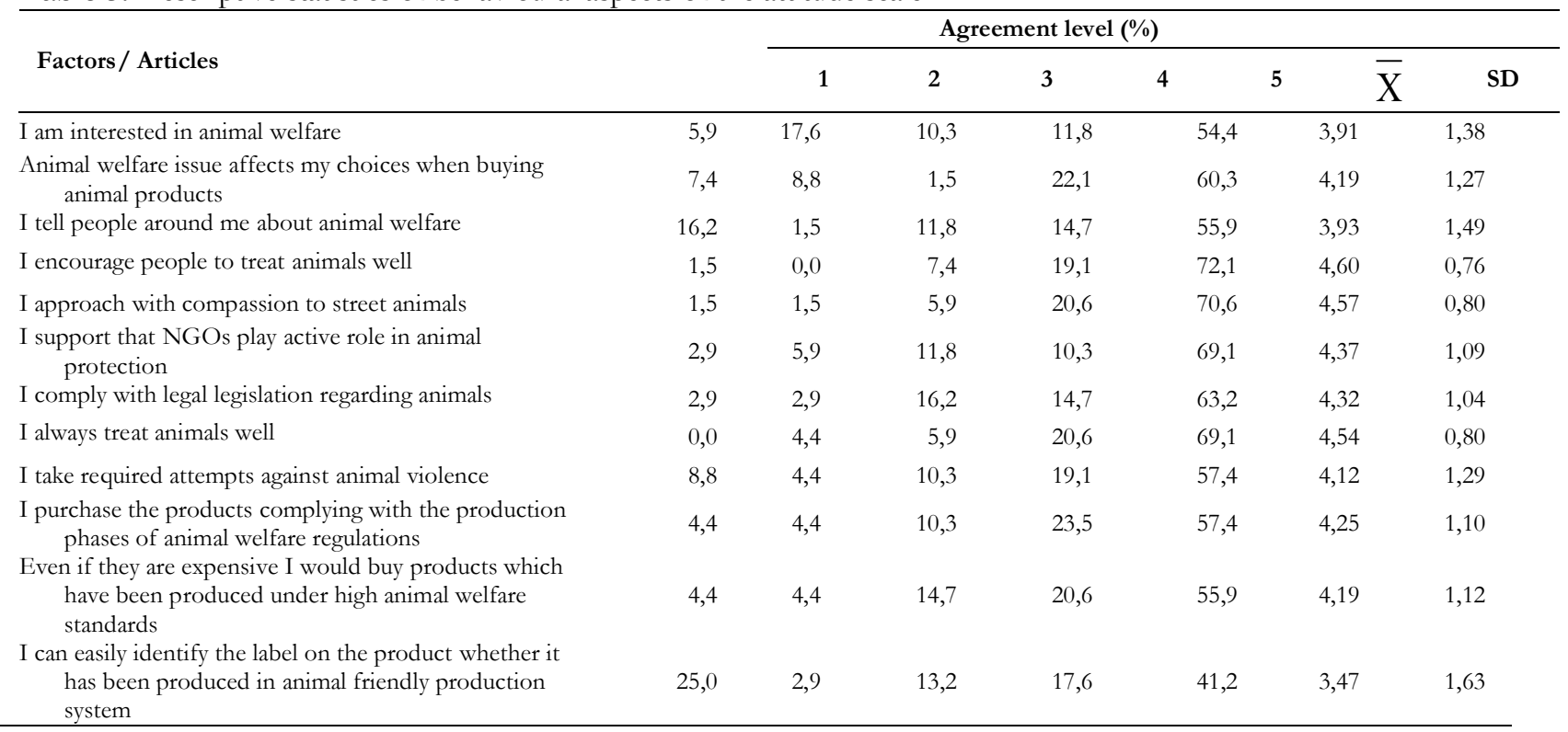

\section{CONCLUSIONS}

In conclusion, the staff in charge of animal handling and transportation in Mus is insufficient with respect to animal welfare knowledge and experience, and their attitude is shaped mostly by cognitive and emotional aspects. Regarding the attitudes of animal transport staff on animal welfare, cognitive aspect is higher compared to emotional and behavioural ones and those personnel who deal with the animals' care during transport think that natural conditions are more effective. Moreover, animal welfare is not understood sufficiently by those. In addition, there is a need for training these people particularly on animal health, pain, modifications and surgical procedures. This study has come to the conclusion that in order to improve human-animal relations and its quality and ultimately animal welfare, the staff employed in the whole process must be evaluated thoroughly and the fact that most transportations out of Mus consist of at least 8 or more hours of traveling should be taken into consideration in order to benefit from cognitive behavioural intervention techniques.

\section{REFERENCES}

Anonim. Karayolu Taşımacıllğı Sektöründe İstihdam; UND raporu. Uluslararas1 Nakliyeciler Derneği, İstanbul 2013 (http://www.lojistikhatti.com/haber/2013/06 /karayolu-tasimaciligi-sektorunde-istihdam).

Baxter SH, Baxter MR, MacCormack JA. Farm Animal Housing and Welfare. (Eds) 1983; Boston, Martinus Nijhoff Publisher.

Boivin X, Le Neindre P, Chupin JM, Garel JP, Trillat G. Influence of bread and early management on ease of handling and openfield behaviour of cattle. Applied Animal Behaviour Science 1992; 32(4): 313-323.

Bozkurt Z, Kılıç İ, Gücüyener Hacan Ö, Lenger ÖF. İnsan-hayvan etkileşimlerinin hayvan refahına etkisi. Kocatepe Veteriner Dergisi 2013; 6(1): 41-50. 
Broom DM. "The welfare of livestock during transport." In: M. Appleby, V. Cussen, L. Garcés, L. Lambert and J. Turner (Eds) Long Distance Transport and the Welfare of Farm Animals.2008; Wallingford, CABI, 157-181.

Coleman GJ. Personnel management in agricultural systems. In Rollin BE and Benson GJ. (Eds) Maximizing Well-being and Minimizing Suffering in Farm Animals. Iowa State University Press, Iowa, 2004; 167-181.

Coleman GC, Hemsworth PH, Hay M, Cox M. Predicting stockperson behaviour towards pigs from attitudinal and job-related variables and empathy. Appl. Anim. Behav. Sci.1998; 58:63-75.

Dockes AC, Kling-Eveillard F. Farmers and advisers representations of animals and animal welfare. Livest. Sci. 2006; 103(3): 243-249.

English P, Burgess G, Segundo R, Dunne J. Stockmanship: Improving the care of the pig and other livestock. Farming Press, Ipswich, UK, 1992.

Furnham A, Heyes C. Psychology students' beliefs about animals and animal experimentation. Personality and Individual Differences, 1993; 15: 1-10.

Gonyou HW, Hemsworth PH, Barnett JL. Effects of frequent interactions with humans on growing pigs. Applied Animal Behaviour Science, 1986; 16(3): 269-278.

Grandin T. Maintenance of good animal welfare standards in beef slaughter plants by use of auditing programs. Journal of the American Veterinary Medical Association, 2005; 226: $370-373$.

Hemsworth PH, Coleman GJ. The stockperson and the productivity and welfare of intensively farmed animals. Human-Livestock Interactions: CAB International, Wallingford, UK; 1998.

Hemsworth P, Coleman GJ. Managing poultry: human-bird interactions and their implications. In The Welfare of Domestic Fowl and Other Captive Birds. Ed. Duncan IJH, Hawkins P, Springer Netherlands 2010; 219-235.

Hemsworth PH, Coleman GJ, Barnett JL, Borg S. Relationships between human-animal interactions and productivity of commercial dairy cows. Journal of Animal Science, 2000; 78(11): 2821-2831.
Herzog HA, Betchart NS, Pittman RB. Gender, sex role orientation, and attitudes toward animals. Anthrozoos.1991; 4: 184-191.

Hills A. Empathy and belief in the mental experience of animals. Anthrozoos.1995; 8(3):132-142.

İnceoğlu M. Tutum, Alg1 ve İletişim. Beykent Üniversitesi Yayınevi, İstanbul; 2010.

Kan CJ, Jager LP, Grommers FJ. Feed additives: do they add to animal welfare? An evaluation. Animal Welfare 1998; 7(4): 397-414.

Karpat Çatalbaş G. Kadınların İşgücüne Katılımını Belirleyen Faktörlerin Belirlenmesi: Panel Veri Yaklaşım1, Kafkas Üniversitesi İIBF Dergisi. 2015; 6(10):249-280.

Kauppinen T, Vesala KM, Valros A. Farmer attitude toward improvement of animal welfare is correlated with piglet production parameters. Livestock Science 2012; 143: 142 150.

Kellert SR. Human-animal interactions: a review of American attitudes toward wild and domestic animals in the twentieth century. In: A.N. Rowan (Ed.), Animals and People Sharing The World, Hanover, NH: University Press of New England 1988; 137-175.

Kellert SR, Berry JK. Attitudes, knowledge, and behaviours towards wildlife as affected by gender. Wildlife Society Bulletin, 1987; 15: 363-371.

Kılıç İ, Bozkurt Z. The relationship between farmers' perceptions and factors affecting sheep welfare. Asian-Australasian Journal of Animal Sciences 2013; 26(9): 1329-1338.

Kılıç İ, Bozkurt Z. Bilişsel, duyuşsal ve davranışsal boyutta hayvan refahı tutum ölçeği ile hayvan refahını etkileyen faktörlere ilişkin alg1 ölçeğinin geliştirilmesi ve hayvan haklarına yönelik katıllımcı görüşlerinin belirlenmesi. Afyon Kocatepe Üniversitesi Bilimsel Araştırma Projesi Kesin Sonuç Raporu, 2014; Proje No: 12.Vf.02.

Kılıç İ, Bozkurt Z, Tekerli M, Koçak S, Çelikeloğlu K. The perceptions of employees in Afyonkarahisar sheep enterprises on factors affecting the animal welfare. Lalahan Hay. Arast. Enst. Derg. 2013; 53(1:29-38.

Kielland C, Skjerve E, Osteras O, Zanella AJ. Dairy farmer attitudes and empathy toward 
animals are associated with animal welfare indicators. Journal of Dairy Science.2010; 93(7): 2998-3006.

Köhler F. Consumer concerns about animal welfare and the impact on food choice. Report on National Survey-Germany 2001; Report of Project EU FAIR, CT98-3678.

Kutanis RÖ. Davranış Bilimleri Tutum. 2013. ErişimAdresi:/http://halksagligi.med.ege.edu.t r/seminerler/200304/TutumOlcegiGelistirme _SK.pdf].Erişim Tarihi:25.06.2013

Likert R. The Human Organization: Its Management and Value. McGrow-Hill; New York, USA; 1967.

Maria GA. Public perception of farm animal welfare in Spain. Livestock Science 2006; 103(3): 250 256.

Napolitano F, Serrapica M, Braghieri A. Contrasting Attitudes towards animal welfare issues within the food chain. Animals 2013; 3(2), 551-557.

Ormandy EH, Julie D, Gilly G. Genetic engineering of animals: ethical issues, including welfare concerns. The Canadian Veterinary Journal 2011; 52 (5): 544.

Pascual-Alonso M, Miranda-de la Lama GC, Aguayo-Ulloa L, Villarroel M, Mitchell M, María G A. Thermophysiological, haematological, biochemical and behavioural stress responses of sheep transported on road. Journal of Animal Physiology and Animal nutrition. 2016; 1-11.

Paul ES, Serpell JA. Childhood pet keeping and humane attitudes in young adulthood. Animal Welfare 1993; 2: 321-337.

Pifer L, Shimizu K, Pifer R. Public attitudes toward animal research: some international comparisons. Society and Animals 1994; 2(2): 95-113.

Tozkoparan G. Davranış Bilimleri Tutum. Dördüncü Bölüm; 2013. Erişim Adresi: [http://www.eytpe.net/wpcontent/uploads/2012/09/Davran-

$\% \mathrm{C} 4 \% \mathrm{~B} 1 \% \mathrm{C} 5 \% 9 \mathrm{~F}-\mathrm{Bilimleri-Tutum}$.ppt]. Erişim Tarihi:15.06.2013

Trunkfield HR. Broom 1990. The welfare of calves during handling and transport. Appl. Anim. Behav. Sci. 1990; 28:135-152.
Van Poucke E, Vanhonacker F, Nijs G, Breackman J, Verbeke W, Tuyttens F. Defining the concept of animal welfare: integrating the opinion of citizens and other stakeholders. In: Ethics And The Politics Of Food. Kaiser M. \& Lien M.E. (Eds), Wageningen Academic Publishers (NL)2006; 555-559.

Waiblinger S, Menke C, Coleman G. The relationship between attitudes, personal characteristics and behaviour of stockpeople and subsequent behaviour and production of dairy cows. Appl. Anim. Behav. Sci. 2002; 79: 195- 219.[http://www.eytpe.net/wpcontent/uploads/2012/09/Davran$\% \mathrm{C} 4 \% \mathrm{~B} 1 \% \mathrm{C} 5 \% 9 \mathrm{~F}-\mathrm{Bilimleri-Tutum}$.ppt]. Erișim Tarihi:15.06.2013 